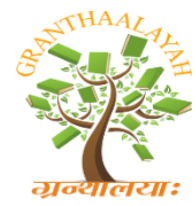

INTERNATIONAL JOURNAL OF RESEARCH GRANTHAALAYAH A knowledge Repository

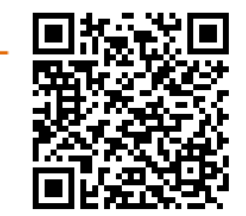

Social

\title{
CLASS ROOM CLIMATE IN RELATION TO THEIR ACADEMIC ACHIEVEMENT AMONG STUDENTS AT SECONDARY LEVEL
}

\author{
K. Tharanie ${ }^{* 1}$, D. Geetha ${ }^{2}$ \\ ${ }^{* 1}$ MEd Scholar, RVS College of Education, India \\ ${ }^{2}$ Assistant Professor in English Education, RVS College of Education, India
}

DOI: https://doi.org/10.29121/granthaalayah.v5.i5(SE).2017.1960

\begin{abstract}
Classroom climate refers to the prevailing mood, attitudes, standards, and tone that teachers and students feel when they are in the classroom. A negative classroom climate can feel hostile, chaotic, and out of control. A positive classroom climate feels safe, respectful, welcoming, and supportive of student learning. The study aimed to examine the class room climate in relation to academic achievement among students at higher secondary levels. The investigator adopted survey method to study the class room climate in relation to academic achievement among students at higher secondary levels. For this study a sample of 300 higher secondary students from five Govt and Private schools which are situated in and around Coimbatore district in Tamil Nadu were selected by the investigator using simple random sampling technique. The findings reveal that there is no significant relationship between class room climate and academic achievement among selected students at higher secondary levels.
\end{abstract}

Keywords: Education; Students; Classroom; Schools \& Higher Secondary.

Cite This Article: K. Tharanie, and D. Geetha. (2017). "CLASS ROOM CLIMATE IN RELATION TO THEIR ACADEMIC ACHIEVEMENT AMONG STUDENTS AT SECONDARY LEVEL." International Journal of Research - Granthaalayah, 5(5)SE, 11-15. https://doi.org/10.29121/granthaalayah.v5.i5(SE).2017.1960.

\section{Introduction}

Education has become highly competitive and commercial in many countries. It is on the basis of high academic performance that students get selected to good secondary schools, better courses of study, and eventually better jobs. Academic achievement has become a yardstick of self worth and success. The outcome of education determines the quality of life, progress and status of people living anywhere in the world (Mayuri \& Devi, 2003). Academic performance is a complex behavior. Research has consistently shown that academic achievement is not an outcome of any single factor; rather it is the result of the interplay of a large number of factors (Gupta, 1993). Many reasons have been advanced as the cause of high rates of failure, including 
bad study habits, low IQ, faulty teaching methods, erroneous examination systems, social and economic disparities etc.

Classroom plays important and vital role in students' performance and behavior modification. Classrooms environment are the catalysts of change; they are the torch bearers always lighting the path towards progress of the world in all its facets.

Classroom climate is defined as the type of environment that is created for students by the school, teachers, and peers. Teachers are continually looking to create a "positive" classroom climate in which student learning is maximized (Bilbo et all, 2012). It is having an environment where students feel safe, nurtured, and intellectually stimulated. This type of positive classroom climate allows students to meet their basic needs of physical and mental health. While there is no specific definition of what creates a negative classroom climate, it is considered to be one in which students feel uncomfortable, whether physically, emotionally, or academically, for any reason. There are two aspects of classroom climate: the physical and social environment. Physical environment refers to the arrangement of chairs, tables, fixtures and pieces of furniture, the painting, lighting and ventilation while the social environment refers to the leadership exhibited by the teacher like democratic, authoritarian and laissez-faire and the mode of students' participation such as collaborative, individualistic or competitive (David, 2002).

The classroom climate influences the student achievement, their self-esteem and participation in the lesson. The most important aspect of classroom climate is the relationship between teacher and students. There must be elements of caring, trust and respect in the interpersonal relationships between teachers and students. An effective classroom climate is one in which the teachers' authority to organize and manage the learning activities is accepted by the students. There is mutual respect and good rapport, and the atmosphere is one of purposefulness and confidence in learning. A key consideration is the extent to which the teacher is able to foster favorable perceptions towards learning among students, by establishing in students self-respect and self-esteem regarding themselves as learners.

The Classroom Climate refers to the general flow of behaviour and feeling with in a group. Classroom climate is the type of environment that is created for students by the school, teachers and peers. Teachers are continually looking to create a "positive classroom climate in which student learning is maximized". Classroom climate is as encompassing all the sociopsychological dimensions of classroom life. This included common interest and the pursuit of common goal achieved through focused, organized and well planned lessons.

Positive classroom climates characterized by positive and supportive teacher-child relationships and interactions have been shown to influence students' psychosocial adjustment in preschool and later grades (Hamre \& Pianta, 2005), and to improve student's social competencies with peers (Pianta, 1999). This is especially important as students' abilities to relate well to peers are especially important for adaptive school functioning and adjustment, as it has been shown to be an especially important area of social growth (Pianta, 1999). The development of children's social competencies is associated with a positive classroom environment and teachers who provide a nurturing context for positive peer interactions (Howes, Phillips, \& Whitebrook, 1992). Indeed, results from multiple studies have indicated that increased exposure to sensitive teachers 
and positive classroom climates is associated with greater teacher-rated social competence (Howes, 2000; Pianta et al., 2002).

Academic achievement represents performance outcomes that indicate the extent to which a person has accomplished specific goals that are the focus of activities in instructional environments such as school, college, and university. Therefore, academic achievement sets the limits as to whether one can take part in higher education. It also decides the kind of career one can take up after the completion of formal education. Besides individual development, academic achievement is of utmost importance for the wealth of a nation and its prosperity.

\section{HYPOTHESIS 1:}

There is no difference in the level of class room climate in relation to their academic achievement of students at secondary level.

Table 1: Frequency and percentage difference in the level of class room climate in relation to their academic achievement of students at secondary level.

\begin{tabular}{|l|l|l|l|l|l|l|l|l|l|}
\hline NAME OF THE & \multicolumn{3}{|l|}{ LOW } & \multicolumn{3}{l|}{ MODERATE } & \multicolumn{2}{l|}{ HIGH } \\
\cline { 2 - 10 } VARIABLES & Q1 & F & \% & Q2 & F & \% & Q3 & F & \% \\
\hline $\begin{array}{l}\text { CLASS ROOM } \\
\text { CLIMATE }\end{array}$ & 77 & 77 & $25.66 \%$ & 82 & 131 & $43.66 \%$ & 87 & 92 & $30.66 \%$ \\
\hline $\begin{array}{l}\text { ACADEMIC } \\
\text { ACHIEVEMENT }\end{array}$ & 355 & 84 & $28 \%$ & 384 & 137 & $45.66 \%$ & 412 & 79 & $26.33 \%$ \\
\hline
\end{tabular}

Table 1. exhibits the result of class room climate in relation to their study habits and academic achievement of students at secondary level. According to the table, totally $25.66 \%$ of the students at secondary level belong to low level of class room climate, $43.66 \%$ of the students at secondary level belong to moderate level of class room climate, and $30.66 \%$ of the students at secondary level belong to high level of class room climate.

According to the table totally $28 \%$ of the students at secondary level belong to low level of academic achievement, $45.66 \%$ of the students at secondary level belong to moderate level of academic achievement, and $26.33 \%$ of the students at secondary level belong to high level of academic achievement.

So the hypothesis No: 1 is accepted. Thus it is inferred that there is a difference in the level of class room climate in relation to their academic achievement of students at secondary level.

\section{HYPOTHESIS 2:}

There is no relationship between the classroom climate and academic achievement of students at secondary level. 
Table 2: Relationships between the classroom climate and academic achievement of students at secondary level.

\begin{tabular}{|l|l|l|}
\hline VARIABLES & N & 'r' Value \\
\hline $\begin{array}{l}\text { Class room } \\
\text { climate }\end{array}$ & 300 & \multirow{2}{*}{.391} \\
\cline { 1 - 2 } $\begin{array}{l}\text { Academic } \\
\text { achievement }\end{array}$ & 300 & \\
\hline
\end{tabular}

The table 2 shows the relation between the class room climate and academic achievement of students at secondary level. According to this table the correlation value (.391) between class room climate and academic achievement has a mild positive correlation. Hence this hypothesis 2 is rejected and it can be concluded that there is a mild positive correlation between class room climate and academic achievement of students at Secondary level.

\section{HYPOTHESIS 3:}

There is no significant mean score difference in class room climate of students at secondary level between the group based on gender.

Table 3: Means score difference and t-test of class room climate of students at secondary level between the group based on gender.

\begin{tabular}{|c|c|c|c|c|c|c|c|c|}
\hline S.No & Gender & $\mathbf{N}$ & Mean & S.D & df & t-value & p-value & Result \\
\hline 1. & Boys & 121 & 81.88 & 9.110 & \multirow{3}{*}{300} & \multirow{3}{*}{.674} & \multirow{3}{*}{.010} & \multirow{3}{*}{$S$} \\
\hline 2. & Girls & 179 & \multirow{2}{*}{81.24} & \multirow{2}{*}{7.190} & & & & \\
\hline 3. & Total & 300 & & & & & & \\
\hline
\end{tabular}

The Table 3 shows that mean score difference in class room climate of students at secondary level between the groups based on gender. The calculated t-value is statistically significant at 0.05 levels and hence, the hypothesis 3 is rejected. It can be concluded that there is a significant difference in class room climate of students at secondary level between the group based on gender.

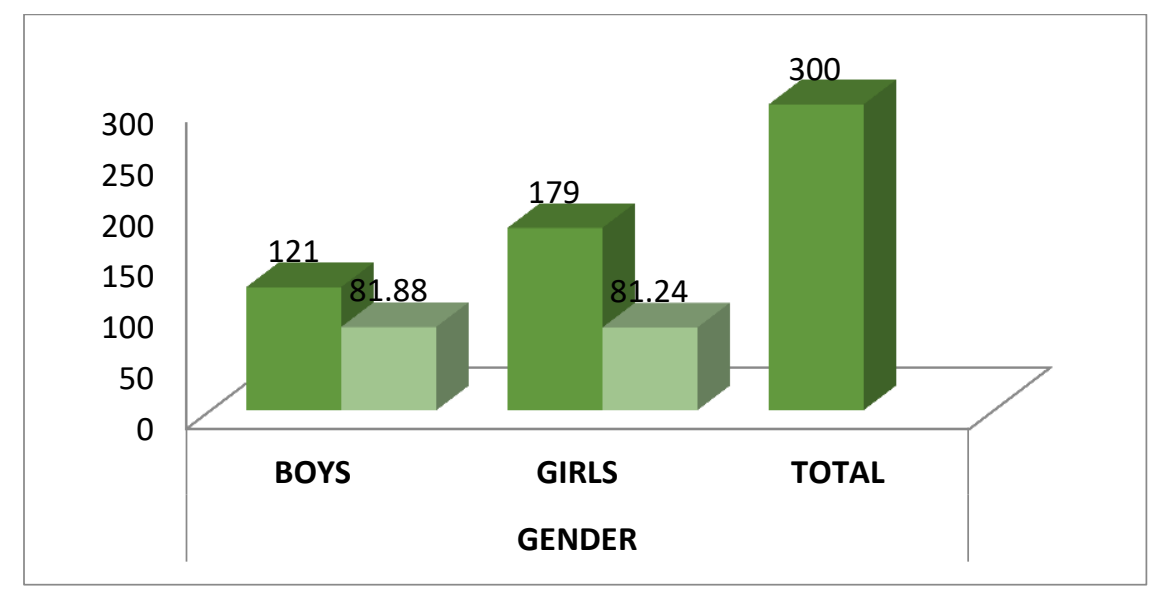

CHART 1: MEANS SCORE DIFFERENCE IN CLASS ROOM CLIMATE BASED ON GENDER 


\section{Conclusion}

The findings reveal that there is a mild positive relationship between class room climate and academic achievement of students at Higher Secondary level. Also $43.66 \%$ of students belong to moderate level of class room climate and $45.66 \%$ of students belong to moderate level of academic achievement. There is a significant mean score difference in class room climate of students at secondary level between the group based on gender. Boys have better mean value than girls.

\section{References}

[1] Anderson, C. (1982). The search for school climate: A review of the research. Review of Educational Research, 52, 368-420.

[2] Bryk, A., \& Driscoll, M. (1988). The school as community: Theoretical foundations, contextual influences, and consequences for students and teachers. Madison, WI: University of Wisconsin, National Center on Effective Secondary Schools.

[3] Chavez, R. (1984). The use of high-inference measures to study classroom climates: A review. Review of Educational Research, 54(2), 237-261.

[4] Golden, S. A. R. (2011). Problems and Prospectus of Distance Education. Quality Enhancement In Distance Education For Life Long Learning, 1(1), 343-344.

[5] Golden, S. A. R. (2016). RURAL STUDENTS' ATTITUDE TOWARDS ENGLISH AS MEDIUM OF INSTRUCTION IN HIGHER EDUCATION - AN ANALYSIS. International Journal of Research, 3(Special Issue - 16), 1-10.

[6] Golden, S. A. R. (2017). Attitude of Students and Teachers towards E- Learning - An Analysis. Recent Research in Social Science \& Humanities, 1, 5-10.

[7] Golden, S. A. R. (2017). Recent Research In Social Science \& Humanities.

[8] Marcon, R. (1999). Demographic and educational influences on academic motivation, competence, and achievement in minority urban students (ISBN 0-674-79265-3). Cambridge, MA: Harvard University Press. (ERIC Document Reproduction Service No. ED 430 061)

[9] Schaps, E., Lewis, C., \& Watson, M. (1997). Building classroom communities. Educational Leadership, 14-17. 